\title{
State, BUMN (State Owned Enterprises - SOEs) and Rule of Law in Economic Development: A Theoretical Approach
}

\author{
Teuku Syahrul Ansari \\ Ph.D Candidate at University of Diponegoro, Semarang, Indonesia
}

\begin{abstract}
:
In developing the Business Judgment System for State-Owned Enterprises (SOEs, Persero) in Indonesian Economic Law, it is necessary to elaborate on the theory of the rule of law in economic development. According to J.D. Mrs. Hart has three elements that must be developed in the legal system so that the law plays a role in economic development, namely predictability, stability, justice (fairness). The rule of the law, basically refers to the main purpose of the law, which is to create an orderly society. Order and balance in society need to be achieved, so that human interests will be protected in achieving their goals. In general, the law functions to divide rights and obligations, regulate how to solve legal problems and maintain legal certainty. The rule of the law basically refers to the main objective of the law, which is to create an orderly society. Order and balance in society need to be achieved, so that human interests will be protected in achieving their goals. In general, the law functions to divide rights and obligations, regulate how to solve legal problems and maintain legal certainty. The focus of this paper is the interaction of Indonesian corporate law in the Indonesian Economic Law system in the management of state-owned enterprises, as one of the corporations with legal status to be able to compete globally, because this principle is a universal principle. Corporate law and globalization interact in the same social space and interests. With these interactions, it allows various possibilities, such as integration, incoordination (partial merging), competition (each running alone), conflict (conflicting), and avoidance (one of the laws avoids the enforcement of other laws).
\end{abstract}

Keyword:

BUMN; business judgement rule; law; good corporate governance; state-owned enterprises.

\section{Introduction}

In Indonesia, the presence of State Owned Enterprises (SOEs or BUMN) in the economy plays a very important role: First, as an agent of development and Second, as a business entity that aims to make a profit. (BUMN or State-Owned Enterprises) is a pillar of the strength of the national economy. However, in the post-Soeharto era of reform, it must be recognized that the existing SOEs, as in the Suharto New Order era, had become a spoil or struggle for political forces (political parties). In the post-Soeharto New Order reform era (1999-2019), in general political competition found 'reincarnation' on fertile land ', namely SOEs and bureaucracy with the aim of seizing publicly available political-economic resources.

As one of the economic actors, SOEs are required to play a strategic role in national development. Even though it is different from private business entities, SOEs in addition to carrying out the mission as a national development agent are also trying to achieve maximum profits. The problems faced by BUMN in principle are divided into two problems, namely internal problems and external problems. Internal problems that are challenging for SOEs are HR professionalism, organizational structure and systems, financial difficulties, and the implementation of Good Corporate Governance, namely good corporate management. HR professionalism in facing more competitive competition is demonstrated by the granting of 
authority and autonomy which means freedom to manage flexibly, initiative, speed, and resultsoriented.

The structure and system of BUMN organizations have an impact on the cost of labor in SOEs which is greater because the number of workers is more than needed. Most SOEs have a fat organizational structure so that a lot of work is done uneconomically. This is based on improper and poorly coordinated human resource planning. Organizational management requires a more dynamic strategy and style. BUMN as one of the national economic actors must implement the right strategy to be able to compete in an increasingly tighter situation. The steps that must be taken by SOEs are to make improvements concerning the organization's structure, culture, and internal systems.

The step in empowering BUMN management becomes a priority to be more responsive to changes in the market environment. Strategies to be used in SOEs need to be followed in terms of adaptation to the structure of the organizational culture so that improvements are needed. Organizational reform is mainly associated with a fundamental overhaul of organizational structures that are able to adapt and adopt innovations that arise from the external environment. The fundamental problem for every SOE is financial difficulties.

\section{Review of Literature}

As a corporation with legal status, the management of state-owned enterprises (SOEs, BUMN) must meet good corporate governance principles, known as Good Corporate Governance. Especially in the accountability of directors or administrators (including commissioners), experts see that there are still unclear standards for measuring the accountability of directors and commissioners.

For example, the "good faith" measure in previous corporate law, there is no clear measure, so that in its implementation it is difficult to determine the size when a director acts in good faith or not. Even though this is important, remembering that a director and commissioner is a risk taker who aims to make a profit, where the directors in making their decisions are often speculative and tend to suffer losses.

In order to strengthen the existence of the SOEs (BUMN- BUMN), a holding company was formed. The holding company functions as a holding company whose role is to plan, coordinate, consolidate, develop, and control in order to optimize the overall performance of the company, including its subsidiaries and affiliates. Companies in the form of holding companies can reap some benefits.

If viewed from the financial side, the advantage that can be learned is the ability to evaluate and choose the best business portfolio for the effectiveness of invested investment, optimizing the allocation of resources owned, and better tax management and planning. Meanwhile, if viewed from the non-financial side, there are a number of benefits. Form Holding Company enables companies to build, control, manage, consolidate and coordinate activities in a multibusiness environment. Also guarantees, encourages, and facilitates parent companies, subsidiaries and affiliates to improve performance. Equally important is to build synergies between companies that are members of the Holding Company and provide support for efficiency.

From the leadership side, there was also institutionalization of individual leadership into the system. The development process and management of Holding Company (Holding Company 
Management) is carried out through a series of stages. The first step that must be done is an understanding of the definition, characteristics, and key factors supporting the success of a Holding Company.

Corporate law and globalization interact in the same social space and interests. With these interactions, it allows various possibilities, such as integration, incoordination (partial merging), competition (each running alone), conflict (conflicting), and avoidance (one of the laws avoids the enforcement of other laws). The presence of Law Number 19 of 2003 concerning State-Owned Enterprises, is not possible to be released from the existence of one of the five possibilities as mentioned above.

In reality, on the one hand, corporate law as something that lives in society, is recognized conditionally in legislation. On the other hand, the influence of globalization makes corporate law unable to function properly.

In fact, with the concept of the right to control the state, it does not reduce the meaning of the philosophy of purpose to the greatest prosperity of the people from the management of the SOEs (BUMN). The principle of the Business Judgment Rules, as an area of corporate jurisdiction, in Indonesian Economic Law, which regulates the extent to which the directors' responsibilities in managing the corporation. Ansari (2019) argues that Business Judgment Rule basically adheres to the principle that a company's directors cannot be held accountable for losses arising from a decision-making action, as long as the directors in making these decisions have been based on good intentions and are entirely in the interest company. In this case, the concept of corporate law is a legal product formed in the context of economic development, because state-owned enterprises are economic actors, should be able to maintain a balance of values in ideology, constitution and globalization in the Indonesian Economic Law system. In this connection, the interaction of globalization with corporate law based on ideology and constitution has a dilemma situation, because in substance the state finances are in the realm of public law, while in its activities, besides providing services to the public also must implement good business principles. This situation finally affected the management of SOEs (BUMN).

In general, the problems that exist in SOEs (BUMN) are the dilemma between being a business pioneer and implementing values in the constitution, specifically Article 33 paragraph (2) of the 1945 Constitution of the Republic of Indonesia. On the other hand, the Constitutional Court has ruled that state-owned finance is state finances managed under the principle of business judgment rules. The formulation of the Constitutional Court caused confusion in its implementation, because it was not easy to use state money in the context of business interests. On the one hand it is intended to provide services to the public, but on the other hand it is carried out with business principles as carried out by the private sector.

Referring to the function of the state which adheres to the concept of the welfare state, causes the state to play an important role in managing SOEs. The concept of the Welfare State in the 1945 Constitution was first adopted by Muhamad Hatta ${ }^{1}$, which can be put forward based on the provisions of Article 33 which reads:

1) The economy is structured as a joint effort based on family principles.

2) Production branches which are important for the state and which control the livelihoods of the public are controlled by the state.

${ }^{1}$ Asshiddiqie, J. (1998). “Undang-Undang Dasar 1945: Konstitusi Negara Kesejabteraan dan Realitas Masa Depan”, University of Indonesia, Jakarta. 
3) The earth and water and the natural resources contained therein shall be controlled by the state and used for the greatest prosperity of the people.

4) The national economy shall be implemented based on economic democracy with the principles of togetherness, efficiency, justice, sustainability, environmental insight, independence, and by maintaining a balance of progress and national economic unity.

5) Further provisions regarding the implementation of this Article are regulated in the Law.

In western countries, the idea of a rule of law can be said to have started since Plato put forward his concept that "good governance is based on good regulation (law) which he calls "Nomol". The rule of law is a translation of the terms rechstaat and the rule of law. ${ }^{3}$

But between the two there are differences, rechstaat as stated by Roscoe Pound has an administrative character, while the rule of law is judicial. The term rechstaat became popular in Europe since the 19th century although the idea of it has been around for a long time. While the term the rule of law became popular with the publication of a book from A.V Dicey in $1885 .{ }^{4}$ with the title Introduction to the Study of Law of the Constitution. Rechstaat comes from the legal traditions of Continental European countries which originate in civil law, while the rule of law develops from the legal traditions of Anglo Saxon countries that develop common law (unwritten law). Although there are differences between rechstaat and the rule of law, both concepts are equally aimed at providing recognition and protection of human rights.

The features of rechstaat are (a) the existence of a constitution or constitution which contains written provisions concerning the relationship between the authorities and the people; (b) the distribution of state power; and (c) the rights of freedom of the people are recognized and protected. The existence of the Constitution will provide a constitutional guarantee of the principle of togetherness and equality, while the distribution of power to avoid the accumulation of power in one hand is very likely to abuse power.

A.V. Dicey suggests three meanings of the rule of law as follows:

a. Supremacy of law, namely the rule of law that excludes arbitrariness, meaning that a person may only be punished if he violates the law;

b. Equality before the law, which is the same position before the law for ordinary people and for officials;

c. The Constitution is based on individual rights, that is, constitutions are based on individual rights.

Meanwhile, according to Wirjono Prodjodikoro ${ }^{5}$, a rule of law means a country within its territory is:

a. All equipment from the state, especially equipment from the government in its actions both for citizens and in their respective interconnections, must not be arbitrary, but must pay attention to the rules of applicable law.

b. All people (residents) in social relations must comply with applicable legal regulations.

\footnotetext{
${ }^{2}$ Azhary, M. T. (2004). Negara Hukum: Suatu Studi tentang Prinsip-prinsipnya Dilihat Dari Segi Hukum Islam, Implementasinya pada Periode Negara Madinah dan masa Kini. Jakarta: Prenada Media. 88-91.

${ }^{3}$ MD., Moh., M (2006). Membangun Politik Hukum, Menegakkan Konstitusi, Jakarta: LP3ES, 24-25.

${ }^{4}$ Huda, N. (2005). Hukum Tata Negara Indonesia, Jakarta: PT RajaGrafindo Persada, 73.

${ }^{5}$ Prodjodikoro, W.. (1971). Asas-asas Ilmu Negara dan Politik. Bandung: Ersco, 38.
} 
Furthermore Immanuel Kant understands the rule of law as a Nachtwaker staat or Nach twactherstaat ("night watch state") whose job is to guarantee order and public safety. The idea of a rule of law according to Kant's concept is called a liberal rule of law. ${ }^{6}$

Whereas Frederich Julius Stahl argues that the rule of law is characterized by four main elements, namely: (1) recognition and protection of human rights; (2) the state is based on the trias politica theory; (3) the government is organized based on the law (wetmatig bestuur); and (4) there is a state administrative court in charge of handling cases of unlawful acts by the government (onrechmatige overheidsdaad). The idea of a rule of law originating from Stahl is called a formal rule of law, because it places more emphasis on a government based on law. ${ }^{7}$

According to Lee (2017) development primarily meant economic growth or improvement in national income, reflecting efforts to relieve populations in developing countries of prevalent poverty and to reduce economic gaps between developed and developing countries. The concept of development has become more holistic since then, emphasizing non-economic values believed to enhance human life, such as political participation, right to property, gender equality, and access to a clean and safe environment, and the rule of law, as the key elements of development.

In its development, the rule of law, whose task was initially only to guarantee the order and security of the developing community, was to directly take care of the people's interests and welfare, so that the function of the state here was to actively take care of the interests of the community, which was nothing but a characteristic of the welfare state. In a legal state called the material recthstaat, the state is obliged to organize the welfare of the people, so that government interference in managing people's economic interests, political and social interests, cultural and environmental interests and other problems is inevitable. ${ }^{8}$

\section{Discussion}

Theory of Tiered Legal Norms (stufenbautheorie) explains the tiered and multi-layered norm in a hierarchical arrangement, where the norms below apply, are sourced and based on even higher norms. Higher norms apply, sourced and based on higher norms, and so on until finally this "regressus" stops at a norm that cannot be explored further and is hypothetical and fictitious which is called the basic norm (grundnorm). This basic norm is a norm that can no longer be traced who formed it or where it came from. Basic norms are often referred to by other names such as basic norm, fundamental norm or grundnorm. Basic norms are the highest norms that have no basis and are not based on even higher norms, but instead apply presupposedly, which is determined in advance by the community. The Tiered Legal Norm Theory from Hans Kelsen was inspired by a student named Adolf Merkl who argued that a legal norm always had two faces (das Doppelte Rechtsantlitz).

According to Adolf Merkl ${ }^{9}$, the legal norms above are sourced and based on the norms above, but to the bottom they also become sources and become the basis for the legal norms below. In other words, a legal norm is always sourced and based on the norms above it, but to the

\footnotetext{
${ }^{6}$ Wahjono, P. (1998). “Konsep Yuridis Negara Hukum Indonesia, paper, 2, as quoted in Muhammad Tahir Azhary. (2004). Negara Hukum: Suatu Studi tentang Prinsip-prinsipnya Dilihat Dari Segi Hukum Islam, Implementasinya pada Periode Negara Madinah dan masa Kini, Jakarta: Prenada Media, 89.

7 lbid., 89.

8 Indrati, M. F. (2007). Ilmu Perundang-undangan: Jenis, Fungsi, dan Materi Muatan, Jakarta: Penerbit Kanisius, 240.

${ }^{9}$ Ibid., 42.
} 
bottom of the legal norms it also becomes a source and becomes the basis for legal norms that are lower than that.

The Tiered Legal Norm Theory from Hans Kelsen was further developed by his student, Hans Nawiasky, who argues that in addition to the tiered and multi-layered norms, the legal norms of a country are also in groups, namely Group I staatsfundamentalnorm (State Fundamental Norms), Group II staatsgrundgeset (Basic Rules / State Principals), Group III formallgesetz (Formal Law), and Group IV Verordnung \& Autonomie Satzung (implementing regulations and autonomous regulations).

State Fundamental Norms (staatsfundamentalnorm) are norms that are the basis for the formation of a country's constitution or constitution, including its amendment norms. In the Republic of Indonesia, the Fundamental Norm of that State is Pancasila. Then the next group norm is the Basic Rules of the State or the Basic Rules of the State (staatsgrundgesetz), which are groups of norms under the Fundamental State Norms, which are rules that are still basic and are general rules that are outline. In the Basic Rules or Basic Rules of the Country, matters are usually stipulated regarding the distribution of state power at the top of government, and besides that the relationship between state institutions, as well as the relationship between the state and its citizens.

In the Republic of Indonesia, the Basic Rules or Basic Rules of this State are set out in the Body of the 1945 Constitution and constitutional conventions. The next group is the Formal Law group (formallgesetz) which is located under the Basic Rules or Basic Rules of the State, where the legal norms in a law are more concrete and detailed and can be directly applied in the community. Last is the group norm of implementing regulations or autonomous regulations. The regulation group functions to implement the provisions in the law.

Placement of Pancasila as the source of all sources of state law is in accordance with the Preamble to the 1945 Constitution which places Pancasila as the basis and ideology of the state and at the same time the philosophical basis of the nation and state so that any material contained in legislation must not conflict with the values contained in Pancasila. As a state based on law, all aspects of life in the social, national and state fields including government must be based on law. To realize the rule of law, an orderly arrangement is needed, among others in the field of forming legislation. To form good legislation, various requirements relating to the system, principles, procedures for preparation and discussion, preparation and implementation techniques are required.

As a basis for developing legal theory, it refers to legal thinking as a "tool" but as a "means" for community renewal. The main ideas underlying the concept of law as a means of renewal or means of development are:

a. that order and order in development and renewal efforts are indeed desirable, even considered (absolutely) necessary;

b. that law in the sense of rules or legal regulations is expected to be able to direct human activities in the direction desired by development and renewal. . ${ }^{10}$

10 Kusumaatmadja, M. (2006). Konsep-konsep Hukum Dalam Pembangunan, The Center for the Study of Archipelago Insights in collaboration with PT Alumni, Bandung, 88. The concept of development law initiated by Mochtar Kusumaatmadja was later named by his students as "Development Law Theory." 
According to Mochtar Kusumaatmadja, ${ }^{11}$ law has a role as a means of changing society, by explaining that: "Such a function is needed in every society, including people who are building ... that is a society that is changing rapidly, the law does not have enough function to maintain order, it must also be able to help the process of changing society."

Mochtar Kusumaatmadja states that the law is the whole principles and rules governing human life in society, also includes the institutions (institutions) and processes (processes) that apply the rules in reality. ${ }^{12}$

The law used as a means of renewal can be in the form of laws or jurisprudence or both. Considering that in Indonesia as a follower of the civil law regime the role of legislation is more prominent than jurisprudence, the law that is more widely used as a means of renewal is legislation. It is different in countries that adopt a precedent system, so the role of jurisprudence is far more important. Therefore, Mochtar Kusumaatmadja argues that the conception of law as a means of public renewal in Indonesia is broader in scope and scope than in the United States where the theory of Law as a Tool of Social Engineering was born. The reason is because the process of legal reform in Indonesia is more prominent using legislation rather than jurisprudence. ${ }^{13}$

Responding to the Theory of Development Law presented by Mochtar Kusumaatmadja, $\mathrm{S}$. Tasrif argues that the rule of law in development is to ensure that changes occur in an orderly manner, which can be assisted by legislation or court decisions or a combination of both. As is the opinion of Mochtar Kusumaatmadja, S. Tasrif also holds that as a developing country, legal development in Indonesia through legislation plays the most important role, in addition to court decisions. ${ }^{14}$

Thus, according to Mochtar Kusumaatmadja the law not only functions as a tool to maintain order in society, but also functions as a means of community renewal. The function of law as a renewal of society is very important for people who are developing, because the law can help the process of community change in accordance with the desired changes. ${ }^{15}$

The law as a means of community renewal was also stated by Satjipto Rahardjo, who stated that the law was not only used to reinforce the habits and behavior found in the community, but also to direct it towards the desired goals, abolishing the habits which it deemed inappropriate, and

11 Kusumaatmadja, M. (2002). Konsep-Konsep Hukum Dalam Pembangunan, PT Alumni, Bandung, 14. Legal theory as a means of community renewal put forward by Mochtar Kusumaatmadja was inspired by opinion Roscoe Pound who argues that law should be as a tool of social engineering, that is must be able to function as a social institution that can meet all the demands and expectations of the community. See Roscoe Pound. (1922). An Introduction to The Philosophy of Law, Yale University Press, United States, 47.

12 Kusumaatmadja, M. (2002). Konsep-Konsep Hukum Dalam Pembangunan, PT Alumni, Bandung, 14. Legal theory as a means of community renewal put forward by Mochtar Kusumaatmadja was inspired by opinion Roscoe Pound who argues that law should be as a tool of social engineering, that is must be able to function as a social institution that can meet all the demands and expectations of the community. See Roscoe Pound. (1922). An Introduction to The Philosophy of Law, Yale University Press, United States, 47.

${ }^{13}$ Rasjidi, L. and Rasjidi, I. T. (2007). Pengantar Filsafat Hukum, Bandung: Mandar Maju, 4th Edition, 2007. 79-80.

${ }^{14}$ Tasrif, S. (2006). "Tanggapan Atas Prasaran Prof. Dr. Mochtar Kusumaatmadja," in Mochtar Kusumaatmadja, Konsep-konsep Hukum Dalam Pembangunan, Pusat Studi Wawasan Nusantara, Hukum dan Pembangunan bekerjasama dengan Bandung: PT Alumni. 35-36.

${ }^{15}$ Rasjidi, L. and Putra, I. B. W., (2003). Hukum Sebagai Suatu Sistem, Bandung: Mandar Maju. 182-183. 
creating new patterns of behavior ${ }^{16}$. In other words, the law can be used as an instrument that is used consciously to achieve certain goals ${ }^{17}$.

The theory applied to analyze the data in writing this dissertation is the legal system theory from Lawrence M. Friedman ${ }^{18}$, and the rule of law in driving economic development according to J.D. Mrs. Hyart.

According to Lawrence M. Friedman, each legal system always contains three elements, namely structure, substance and legal culture. ${ }^{19}$ First, structure. "First many features of a working legal system can be called structural the moving parts, so speak of-the machine Courts are simple and obvious example; their structures can be described; a panel of such and such size, sitting at such and such a time, which this or that limitation on jurisdiction. The shape size, and power of legislature is another element structure. A written constitution is still another important feature in structural landschape of law. It is, or attempts to be, the expression or blueprint of basic features of the country's legal prosess, the organization and framework of government". ${ }^{20}$

Friedman's description above shows that structure as part of the legal system includes institutions created by the legal system including the judiciary (court), legislature and executive. The component of the legal structure is a representation of the institutional aspect that plays the rule of law enforcement and law making. The structure in its implementation is a uniformity related to one another in a legal system.

Second, substance. Regarding substance, Friedman states:"The second type of component can be called substantive. These are the actual products of the legal system-what the judges, for example, actually say and do. Substance includes, naturally, enough, those propositions referred to as legal rules; realistically, it also includes rules which are not written down, those regulaties of behavior that could be reduced to general statement. Every decision, too, is a substantive product of the legal system, as is every doctrine announced in court, or enacted by legislature, or adopted by agency of government." 21

Third, legal culture. "Legal culture can be defined as those attitudes and values that related to law and the legal system, together with those attitudes and values affecting behavior related to law and its institution, either positevely or negatively. Love of litigation, or a hatred of it, is part of the legal culture, as would be attitudes toward child rearing in so far as these attitudes affect behavior which is at least nominally governed by Law. The legal culture, then is general expression for the way the legal system fits into the culture of the general society."

\section{Conclusion}

Friedman's description above shows that legal culture includes the views, attitudes or values that determine the operation of the legal system. The views and attitudes of the people towards are very varied, because they are influenced by sub-culture such as ethnicity, gender,

\footnotetext{
${ }^{16}$ Rahardjo, S.. (2000). Ilmu Hukum, Bandung: PT Citra Aditya Bakti, 206.

17 Ibid., 209.

${ }^{18}$ Friedman, L. M. (1971). the State and the Rule of Law in Mix Economy (London: Steven \& Son), 70.

${ }^{19}$ Friedman, L. M. (1984). American Law (New York: W.W.Norton and Company), 7.

${ }^{20}$ Lawrence M.Friedman. Ibid. p.29.

${ }^{21}$ Friedman, L. M. (1969). “On Legal Development,” Rutgers Law Review, Vol.23, p. 27
} 
education, descent, beliefs (religion) and the environment. The views and attitudes of this community greatly influence the enforcement of the law.

The use of Friedman's theory is related to the legal system, at least for three reasons; first, in relation to SOEs, the implementation of SOE laws and regulations does not only depend on the substance, but is also influenced by the work of the legal apparatus. Second, the emergence of the development and formulation of SOE policies in a social order that is influenced by values, expectations and orientations that develop in society. Third, the implementation of SOEs (BUMN) regulations is influenced by differences in interests, values, orientation and position of the licensing implementers.

In addition to using legal system theory, this dissertation research will also prove the effectiveness of law in driving economic development. According to J.D. Mrs. Hart there are three elements that must be developed in the legal system so that law plays a role in economic development, namely predictability, stability (stability), fairness.

First, predictability (predictability), namely the law must be able to create certainty. With certainty, investors can predict the consequences of the actions that will be taken and have certainty how other parties will act.

Second, stability. The role of the state empowered by law is basically in order to maintain a balance to achieve a goal. This balance includes the interests of individuals, groups and general interests associated with the challenges being faced both at home and abroad. Through this Act it is hoped that it will accommodate the interests of workers and employers, the interests of economic growth and a clean environment, the interests of large companies and small and medium-sized businesses. In this case whether the law can accommodate or balance competing interests in society.

Third, fairness, namely the law must be able to create justice for the community and prevent unjust and discriminatory practices. Fairness aspects such as due process, equality of treatment and standards of government behavior are a necessity to maintain market mechanisms and prevent the negative impacts of excessive bureaucratic actions. The absence of a standard of justice, is said to be the biggest problem faced by developing countries. In the long run the absence of these standards can result in the loss of the Government's legitimacy. ${ }^{22}$

This study of legal interactions generally aims to obtain the reality of holistic management of SOEs in Indonesian Economic Law, along with the issue of criticizing various issues of globalization and their impact on corporations, and understanding a case as a series of events, constructions and actions, to then offer one legal model building.

\section{References}

Ansari, T. S. (2019). Reminding State Owned Enterprises (BUMN) Management Using the Principle of 'Business Judgment Rule': A Preliminary Note. Birci Journal, 27-38.

Asshiddiqie, J. (1998). "Undang-Undang Dasar 1945: Konstitusi Negara Kesejabteraan dan Realitas Masa Depan", University of Indonesia, Jakarta.

Azhary, M. T. (2004). Negara Hukum: Suatu Studi tentang Prinsip-prinsipnya Dilihat Dari Segi Hukum Islam, Implementasinya pada Periode Negara Madinah dan masa Kini, Jakarta: Prenada Media, 88-91.

${ }^{22}$ Leonard J.Theberge. (1980). Law and Economic Development. Journal of International Law and Policy, 232. 
Friedman, L. M. (1971). The State and The Rule of Law in Mix Economy. London: Steven \& Son. 70 Friedman, L. M. (1984). American Law (New York: W.W.Norton and Company) 7.

Friedman, L. M. (1969). On Legal Development. Rutgers Law Review, 27.

Friedmann, W. (1971). The State and The Rule of Law In A Mixed Economy. London: Steven \& Son, 5. Huda, N. (2005). Hukum Tata Negara Indonesia. Jakarta: PT RajaGrafindo Persada, 73.

Indrati, M. F. (2007). Ilmu Perundang-undangan: Jenis, Fungsi, dan Materi Muatan. Jakarta: Kanisius, 240.

Kusumaatmadja, M. (2006). Konsep-konsep Hukum Dalam Pembangunan, Pusat Studi Wawasan Nusantara bekerjasama dengan Penerbit PT Alumni, Bandung, 88.

Lee, Yong-Shik. (2017). General Theory of Law and Development. Cornell International Law Journal, 2. MD. Moh. M. (2006). Membangun Politik Hukum, Menegakekan Konstitusi. Jakarta: LP3ES, 24-25.

Pound, R. (1922). An Introduction to The Philosophy of Law. Yale University Press, United States, 47. Prodjodikoro, W. (1971). Asas-asas Ilmu Negara dan Politik. Bandung: Ersco, 38.

Rahardjo, S. (2000). Ilmu Hukum. Bandung: PT Citra Aditya Bakti, 206.

Rasjidi, L. and Rasjidi, I. T. (2007). Pengantar Filsafat Hukum. Bandung: Mandar Maju, 79-80.

Rasjidi, L. and Putra, I. B. W., (2003). Hukum Sebagai Suatu Sistem. Bandung: Mandar Maju, 182-183.

Tasrif, S. (2006). "Tanggapan Atas Prasaran Prof. Dr. Mochtar Kusumaatmadja," in Kusumaatmadja, M.

(2006). Konsep-konsep Hukum Dalam Pembangunan, Pusat Studi Wawasan Nusantara, Hukum dan Pembangunan bekerjasama dengan Bandung: PT Alumni, 35-36.

Thaib, D., Hamidi, J. and Huda, N. (1999). Teori Hukum dan Konstitusi. Jakarta: Rajawali Pers. Theberge, L. J. (1080). Law and Economic Development, 'Journal of International Law and Policy, 232.

Wahjono, P. (1998). Konsep Yuridis Negara Hukum Indonesia, paper, 2 as quoted in Tahir, M. A. (2004). Negara Hukum: Suatu Studi tentang Prinsip-prinsipnya Dilihat Dari Segi Hukum Islam, Implementasinya pada Periode Negara Madinah dan masa Kini, Jakarta: Prenada Media, 89. 